\title{
Quantifying dietary macronutrient sources of carbon for bone collagen biosynthesis using natural abundance stable carbon isotope analysis
}

\author{
Susan Jim ${ }^{1}$, Vicky Jones ${ }^{1}$, Stanley H. Ambrose ${ }^{2}$ and Richard P. Evershed ${ }^{1 *}$ \\ ${ }^{1}$ Organic Geochemistry Unit, Bristol Biogeochemistry Research Centre, School of Chemistry, University of Bristol, \\ Bristol BS8 1TS, UK \\ ${ }^{2}$ Department of Anthropology, University of Illinois, Urbana, IL 61801, USA
}

(Received 23 May 2005 - Revised 18 November 2005 - Accepted 22 November 2005)

\begin{abstract}
The diets of laboratory rats were isotopically and nutritionally manipulated using purified $\mathrm{C}_{3}$ and/or $\mathrm{C}_{4}$ macronutrients to investigate the routing of dietary carbon to bone collagen biosynthesis. Diets were formulated with purified proteins, carbohydrates and lipids of defined composition and natural abundance stable isotope ratios. Bulk protein and constituent amino acid $\delta^{13} \mathrm{C}$ values determined for whole diet and bone collagen provided the basis for assessing isotopic fractionation and estimating the degree of routing versus synthesis de novo of essential, non-essential and conditionally indispensable amino acids. Essential and conditionally indispensable amino acids were shown to be routed from diet to collagen with little isotopic fractionation whereas non-essential amino acids differed by up to $20 \%$. Mathematical modelling of the relationships between macronutrient and tissue $\delta^{13} \mathrm{C}$ values provided qualitative and quantitative insights into the metabolic and energetic controls on bone collagen biosynthesis. Essential amino acids comprise $21.7 \%$ of the carbon in collagen, defining the minimum amount of dietary carbon routing. Estimates of 42 and $28 \%$ routing were shown for the non-essential amino acids, glycine and aspartate, respectively. In total, the routing of non-essential and conditionally indispensable amino acids was estimated to equal $29.6 \%$ of the carbon in collagen. When the contribution of carbon from the essential amino acids is also considered, we arrive at an overall minimum estimate of $51.3 \%$ routing of dietary amino acid carbon into bone collagen.
\end{abstract}

Stable carbon isotope analysis: Bone collagen: Amino acid: Natural abudance: Biosynthesis: Feeding experiments: $R$ ats $C_{3} / C_{4}$ diets

Stable isotope analysis is a powerful tool with which metabolic pathways such as biosynthesis and degradation, and their net balance, i.e. rate of turnover, can be traced on the whole body to the compound-specific level. Not only can metabolic insights be gleaned through labelled (Atasoglu et al. 2004; Guillet et al. 2004; Wu et al. 2004) and natural abundance studies (Morrison et al. 2000; O'Brien et al. 2002; Jim et al. 2003, 2004; Ayliffe et al. 2004), but also through monitoring intra-molecular natural abundance stable isotope values (Brenna, 2001; Savidge \& Blair, 2004). Its application in ecological and palaeoecological investigations (Gannes et al. 1998; Bocherens \& Drucker, 2003; Lee-Thorp et al. 2003) demands a rigorous understanding of the isotopic relationship between diet and consumer tissues, i.e. knowledge of the biochemistry underpinning the adage that 'you are what you eat, plus or minus a few per mil'. Controlled diet experiments and well-controlled natural diet observations have established that bone collagen $\delta^{13} \mathrm{C}$ values are ${ }^{13} \mathrm{C}$-enriched by approximately $5 \%$ when compared to whole diet $\delta^{13} \mathrm{C}$ values $\left(\Delta^{13} \mathrm{C}_{\mathrm{COLL}}\right.$-WDiet $=\delta^{13} \mathrm{C}_{\mathrm{COLL}}-$ $\delta_{13} \mathrm{C}_{\text {WDIET }} \approx 5 \%$ o). Early studies of the isotopic composition of tissues of wild and laboratory-reared animals have provided broad insights into the factors that influence the isotopic fractionations observed between diet and consumer tissues
(DeNiro \& Epstein, 1978; Krueger \& Sullivan, 1984; Chisholm, 1986; Tieszen \& Boutton, 1988; Lee-Thorp et al. 1989; Ambrose, 1993). However, many experiments showed substantial deviations in $\Delta^{13} \mathrm{C}_{\text {COLL-WDIET away from this }}$ $5 \%$ value. Explanations for the variation in ${ }^{13} \mathrm{C}$ between whole diet and bone collagen have focused on the extent to which differences in whole diet and dietary protein carbon isotopic composition control bone collagen $\delta^{13} \mathrm{C}$ values. Two controlled diet studies (Ambrose \& Norr, 1993; Tieszen \& Fagre, 1993) showed that $\Delta{ }^{13} \mathrm{C}_{\text {COLL-WDIET }}$ could be systematically varied from approximately $-2 \%$ o to $10 \%$ oby changing the $\delta^{13} \mathrm{C}$ value of dietary protein relative to that of the whole $\operatorname{diet}\left(\Delta^{13} \mathrm{C}_{\text {PROT-WDIET }}\right)$. These experiments demonstrated that the bulk $\delta^{13} \mathrm{C}$ value of bone collagen tracked that of dietary protein rather than whole diet. Therefore, collagen $\delta{ }^{13} \mathrm{C}$ value largely reflects that of dietary protein (Ambrose \& Norr, 1993; Tieszen \& Fagre, 1993). Greater than expected levels of routing (direct absorption) of dietary protein carbon to consumer bone collagen, compared to that defined by the proportion of its essential amino acids (AA) (Fuller \& Garlick, 1994; Reeds, 2000), was observed. This excess indicated that some non-essential AA must have also been absorbed from the diet rather than synthesised de novo using non-protein carbon. The degree to which each non-essential AA behaves like an

Abbreviations: AA, amino acid; $\mathrm{C} 3$, pure $\mathrm{C}_{3}$ diet; $\mathrm{C} 3 \mathrm{P} / \mathrm{C} 4 \mathrm{E}, \mathrm{C}_{3}$ protein/ $\mathrm{C}_{4}$ energy diet; $\mathrm{C} 4$, pure $\mathrm{C}_{4}$ diet; $\mathrm{C} 4 \mathrm{P} / \mathrm{C} 3 \mathrm{E}, \mathrm{C}_{4}$ protein/ $\mathrm{C}_{3}$ energy diet; GC/C/IRMS, gas chromatography/combustion/isotope ratio mass spectrometry.

* Corresponding author: Richard Evershed, fax 44 (0)117 9251295, email r.p.evershed@bristol.ac.uk 
essential AA cannot be determined by bulk isotopic analysis of dietary protein and consumer tissues. Compound-specific isotopic analysis of dietary macronutrients and consumer tissue AA is necessary to address this question.

Collagen contains eighteen AA, predominantly glycine, proline and hydroxyproline. Essential AA and those with essential precursors comprise approximately 18.5-21.7\% of collagen carbon atoms (Francois \& Glimcher, 1967; Ambrose, 1993; Schwarcz, 2000). Isotopic analysis of individual AA show that collagen $\mathrm{AA} \quad{ }^{13} \mathrm{C}$ values can differ by up to $27 \%$ o (Tuross et al. 1988; van Klinken, 1989; Hare et al. 1991). This variation at the molecular level is masked when dietary reconstructions are based on bulk collagen isotopic determinations. In order to develop a fundamental understanding of the relationship between the $\delta^{13} \mathrm{C}$ values of diet and bone collagen, $\delta^{13} \mathrm{C}$ values must be determined at the AA level, and their metabolic and biosynthetic relationships assessed. Recognising this, Hare et al. (1991) investigated the $\delta^{13} \mathrm{C}$ values of bone collagen AA of pigs raised on controlled diets. A wide range of $\delta^{13} \mathrm{C}$ values was observed for these AA and this was attributed to their differing metabolic pathways. However, questions still remained regarding the exact relationship between different dietary macronutrients and the $\delta^{13} \mathrm{C}$ values of the building block AA in bone collagen. Hare et al. (1991) utilised diets in which the dietary macronutrient fractions were not isotopically distinct. Therefore it was not possible to trace and quantify the incorporation of carbon from different dietary macronutrients into bone collagen, i.e. the neosynthesis of non-essential AA from non-protein precursors could not be determined. We describe herein the results of an investigation carried out on rats using natural abundance, isotopically distinct but nutritionally identical formulated diets. Crucially, this experiment included diets where dietary protein and non-protein macronutrients had distinct carbon isotopic compositions, which permitted us to trace their differing contributions to bone collagen biosynthesis. Our aim was to qualitatively and quantitatively assess the dietary macronutrients utilised in the biosynthesis of bone collagen via the compound-specific determination of the $\delta^{13} \mathrm{C}$ values of AA from the diet and bone. As far as we are aware, this represents the first attempt to make such a determination for a mammalian protein using dietary macronutrients that differ naturally in their stable carbon isotope ratios.

\section{Materials and methods}

\section{Experimental animals}

The rat tissues and diets provided for analysis derived from a larger programme of isotopically controlled feeding experiments undertaken at the University of Illinois. Holtzman albino rats were raised on a variety of isotopically distinct, purified and pelletised diets in which the proportions of protein, starch, sucrose and oil were varied. The diets were prepared from purified $\mathrm{C}_{3}$ or $\mathrm{C}_{4}$ foodstuffs and the isotopic $\mathrm{C}$ and $\mathrm{N}$ compositions of the dietary components were precisely characterised. Diet compositions and their carbon isotope values are presented in Table 1. Female Holtzman albino rats were placed on the diet that their offspring would consume $1 \mathrm{~d}$ after insemination. Birth occurred $21 \mathrm{~d}$ later, and weaning began $21-23 \mathrm{~d}$ thereafter. Male and female pairs were killed at 91, 131 and $171 \mathrm{~d}$ after birth. In the present study, eight rats, two each from four distinct diets (Table 2), were randomly selected for stable carbon isotope analysis of individual AA.

\section{Bulk $\delta^{13} C$ analysis of whole diet, dietary macronutrients and bone collagen}

Bulk $\delta{ }^{13} \mathrm{C}$ measurements and bone collagen isolation procedures are summarised here and described in detail in Ambrose and Norr (1993). Lipids were extracted from clean ground bone using petroleum ether and discarded. Collagen was extracted by demineralisation with $0.1 \mathrm{M}-\mathrm{HCl}$, treated with $0 \cdot 125 \mathrm{M}-\mathrm{NaOH}$, solubilised at $95^{\circ} \mathrm{C}$ and freeze-dried. Whole diet, dietary macronutrients and bone collagen were combusted at $>800^{\circ} \mathrm{C}$ with $\mathrm{Cu}, \mathrm{CuO}$ and $\mathrm{Ag}$ foil in evacuated sealed quartz tubes. $\mathrm{CO}_{2}$ was cryogenically distilled off-line, and analysed on dual inlet isotope ratio mass spectrometers at the Anthropology Department, University of Illinois (Nuclide 6-60 RMS) or the Illinois State Geological Survey (Finnigan MAT Delta E).

\section{Isolation of amino acids from diet and bone}

Bone collagen and diets were ground to a powder, solvent extracted, frozen and then freeze-dried. To determine the isotopic composition of individual AA, approximately $1-2 \mathrm{mg}$ of sample was hydrolysed as described previously (Docherty et al. 2001; Howland et al. 2003; Jim et al. 2003). Briefly, $6 \mathrm{M}-\mathrm{HCl}$ was added to the sample $(500: 1, \mathrm{v} / \mathrm{w})$ and heated to $100^{\circ} \mathrm{C}$ under vacuum for $24 \mathrm{~h}$.

\section{Compound specific stable carbon isotope analysis}

The carbon isotope compositions of individual AA were obtained by gas chromatography/combustion/isotope ratio mass spectrometry (GC/C/IRMS). AA were derivatised to trifluoroacetyl isopropyl esters following the method of

Table 1. Diet composition and components

\begin{tabular}{|c|c|c|c|c|c|c|c|}
\hline \multirow[b]{2}{*}{ Diet } & \multicolumn{2}{|c|}{ Composition } & \multicolumn{5}{|c|}{ Components $\left(\delta^{13} \mathrm{C} \%\right.$ \%) } \\
\hline & Protein & Energy* & Protein $(20 \%)$ & Sucrose $(50 \cdot 2 \%)$ & Starch (15.5\%) & Oil (5.0\%) & Cellulose $(5.0 \%)$ \\
\hline D2A & $\mathrm{C}_{3}$ & $\mathrm{C}_{3}$ & Milk casein $(-24.5 \%$ ) & Beet $(-24 \cdot 2 \% \circ)$ & Rice $(-26 \cdot 4 \%$ o & Cottonseed (-27.9\%०) & Wood $(-24 \cdot 1 \%$ ) \\
\hline D3G & $\mathrm{C}_{3}$ & $\mathrm{C}_{4}$ & Milk casein $(-26 \cdot 3 \%)$ & Cane $(-11 \cdot 0 \%$ o & Corn $(-10 \cdot 3 \%)$ & Corn $(-14.9 \% \circ)$ & Corn $(-11 \cdot 3 \% \circ)$ \\
\hline $\mathrm{D} 4 \mathrm{H}$ & $\mathrm{C}_{4}$ & $\mathrm{C}_{4}$ & Milk casein $(-14.6 \%)$ & Cane $(-11.4 \% \circ)$ & Corn $(-10 \cdot 6 \%)$ & Corn $(-14.9 \%$ ) & Corn $(-11 \cdot 2 \%$ o \\
\hline D5I & $\mathrm{C}_{4}$ & $\mathrm{C}_{3}$ & Milk casein $(-14.6 \%$ ) & Beet $(-24 \cdot 2 \% \circ)$ & Rice $(-26 \cdot 4 \%$ o & Cottonseed (-27.9\%०) & Wood $(-24.3 \%$ o \\
\hline
\end{tabular}

* Energy comprises the non-protein components of diet. 
Table 2. Carbon isotopic composition of whole diet, protein, non-protein and bone collagen for all animals raised on the controlled diets*

\begin{tabular}{|c|c|c|c|c|c|c|}
\hline \multirow[b]{2}{*}{ Diet } & \multicolumn{4}{|c|}{$\delta^{13} \mathrm{C}(\% \circ)$} & \multirow[b]{2}{*}{$\Delta^{13} \mathrm{C}_{\text {COLL-WDiet }} \dagger$} & \multirow[b]{2}{*}{ Amino acid study } \\
\hline & Whole diet & Protein & Non-protein & Bone collagen & & \\
\hline \multirow[t]{4}{*}{ D2A } & -24.9 & -24.5 & $-25 \cdot 1$ & $-19 \cdot 7$ & $5 \cdot 2$ & \\
\hline & & & & -19.3 & 5.6 & \\
\hline & & & & $-19 \cdot 8$ & $5 \cdot 1$ & $\ddagger$ \\
\hline & & & & -20.0 & 4.9 & $\ddagger$ \\
\hline \multirow[t]{9}{*}{ D3G } & -14.7 & $-26 \cdot 3$ & $-11 \cdot 3$ & $-17 \cdot 0$ & $-2 \cdot 3$ & \\
\hline & & & & $-16 \cdot 7$ & -2.0 & \\
\hline & & & & $-16 \cdot 9$ & -2.2 & \\
\hline & & & & $-16 \cdot 9$ & $-2 \cdot 2$ & $\ddagger$ \\
\hline & & & & $-17 \cdot 0$ & $-2 \cdot 3$ & $\ddagger$ \\
\hline & & & & $-16 \cdot 9$ & $-2 \cdot 2$ & \\
\hline & & & & $-17 \cdot 0$ & $-2 \cdot 3$ & \\
\hline & & & & $-17 \cdot 0$ & $-2 \cdot 3$ & \\
\hline & & & & $-17 \cdot 0$ & $-2 \cdot 3$ & \\
\hline \multirow[t]{4}{*}{ D4H } & $-12 \cdot 2$ & -14.6 & -11.7 & -7.7 & 4.5 & \\
\hline & & & & -7.9 & $4 \cdot 3$ & $\ddagger$ \\
\hline & & & & -7.7 & 4.5 & \\
\hline & & & & -8.0 & 4.2 & $\ddagger$ \\
\hline \multirow[t]{4}{*}{ D5I } & $-22 \cdot 3$ & -14.6 & $-25 \cdot 1$ & $-12 \cdot 2$ & $10 \cdot 1$ & \\
\hline & & & & $-12 \cdot 6$ & $9 \cdot 7$ & \\
\hline & & & & $-12 \cdot 1$ & $10 \cdot 2$ & $\ddagger$ \\
\hline & & & & -12.5 & $9 \cdot 8$ & $\ddagger$ \\
\hline
\end{tabular}

${ }^{*}$ For procedures and diet composition, see Materials and methods and Table 1.

† Differences between bone collagen and whole diet $\delta^{13} \mathrm{C}$ values $\left(\Delta^{13} \mathrm{C}_{\text {COLL-WDIET }}=\delta^{13} \mathrm{C}_{\mathrm{COLL}}-\delta^{13} \mathrm{C}_{\text {WDIET }}\right)$.

$\ddagger$ Individuals were randomly selected for the amino acid study.

Macko et al. (1997). GC/C/IRMS analyses were performed using a HP 6890 gas chromatograph coupled to a Finnigan MAT DELTA ${ }^{\text {plus }}$ XL isotope ratio monitoring mass spectrometer via a Finnigan MAT GC III combustion interface (electron ionisation $100 \mathrm{eV}$; three Faraday cup collectors $\mathrm{m} / \mathrm{z}$, 44, 45 and $46 ; \mathrm{CuO} / \mathrm{NiO} / \mathrm{Pt}$ combustion reactor set to $940^{\circ} \mathrm{C} ; \mathrm{Cu}$ reduction reactor set to $\left.600^{\circ} \mathrm{C}\right)$. The following $\mathrm{GC}$ conditions were used: column: ZB5 $(60 \mathrm{~m} \times 0.32 \mathrm{~mm} \times 0.25 \mu \mathrm{m})$; injector temperature: $200^{\circ} \mathrm{C}$; temperature programme: $40^{\circ} \mathrm{C}(1 \mathrm{~min})$ to $70^{\circ} \mathrm{C}$ at $10^{\circ} \mathrm{C} \mathrm{min}^{-1}$, then to $170^{\circ} \mathrm{C}$ at $3^{\circ} \mathrm{C} \mathrm{min}{ }^{-1}$, then to $250^{\circ} \mathrm{C}$ at $15^{\circ} \mathrm{C} \mathrm{min}^{-1}$ and then hold isothermally for $15 \mathrm{~min}$. Standardisation of runs was achieved using six aliquots of $\mathrm{CO}_{2}$ gas of known $\delta{ }^{13} \mathrm{C}$ value, which were injected directly into the ion source. Three pre-derivatised trifluoroacetyl methyl ester AA (alanine, phenylalanine and lysine) of known $\delta^{13} \mathrm{C}$ value were employed as co-injected secondary standards. Data were collected and processed using Finnigan MAT Isobase software. Triplicate GC/C/IRMS analyses were carried out on each sample and measured $\mathrm{AA} \delta{ }^{13} \mathrm{C}$ values were corrected for the addition of derivative carbon and its associated kinetic isotope effects via the use of correction factors (Docherty et al. 2001). Errors associated with these calculations varied from \pm 0.6 to $\pm 1.5 \%$ depending on the AA.

$$
\delta^{13} \mathrm{C}_{\mathrm{v}} \operatorname{PDB}(\% \circ)=\left[\left(\frac{{ }^{13} \mathrm{C} /{ }^{12} \mathrm{C} \text { sample }}{{ }^{13} \mathrm{C} /{ }^{12} \mathrm{C} \text { standard }}\right)-1\right] \times 10^{3}
$$

Carbon isotope determinations are made relative to Pee Dee Belemnite (vPDB). ${ }^{13} \mathrm{C} /{ }^{12} \mathrm{C}$ is the ratio of abundances of the stable isotopes of carbon. $\delta^{13} \mathrm{C}$ values have units of parts per thousand or per mil (\%o; Craig, 1957).

\section{Results and discussion}

Bulk diet and bone collagen stable isotopic composition

Whole diet, protein, non-protein and bone collagen $\delta^{13} \mathrm{C}$ values of all animals raised on these four diets are shown in Table 2 (individuals that were randomly selected for the AA study are indicated). Intra-group variations in bone collagen $\delta{ }^{13} \mathrm{C}$ values for animals raised on the same diets ranged from 0.3 to $0.7 \%$ (analytical precision $= \pm 0.1 \%$ ). These data show that inter-individual variance in isotopic composition of animals raised on the same diet is small. Differences between bone collagen and whole diet $\delta^{13} \mathrm{C}$ values, $\Delta^{13} \mathrm{C}_{\mathrm{COLL}}$ WDIET, are also listed. These were found to vary substantially between diets, from $-2 \cdot 0$ to $+10 \cdot 2 \%$.

\section{Mass balance calculations}

Measured AA constitute twelve out of the eighteen AA or $83.8 \%$ of the carbon in bone collagen (collagen AA composition from Francois \& Glimcher, 1967). Thus, the accuracy of individual collagen $\mathrm{AA} \delta^{13} \mathrm{C}$ values can be tested via the calculation of corresponding bulk collagen $\delta^{13} \mathrm{C}$ values using mass balance calculations as follows:

$$
\delta^{13} \mathrm{C}=\sum_{i=1}^{n} \mathrm{~A}_{i} \mathrm{~B}_{i}
$$

where $\mathrm{A}_{i}=\mathrm{AA} \delta^{13} \mathrm{C}$ value, $\mathrm{B}_{i}=$ percentage carbon contribution to collagen molecule and $n=12$. Calculated bulk collagen $\delta^{13} \mathrm{C}$ values were shown to correlate extremely well $\left(R^{2}\right.$ $0.95 ; P \leq 0.001$ ) with measured values (Fig. 1 ) with only small differences between measured and calculated values 


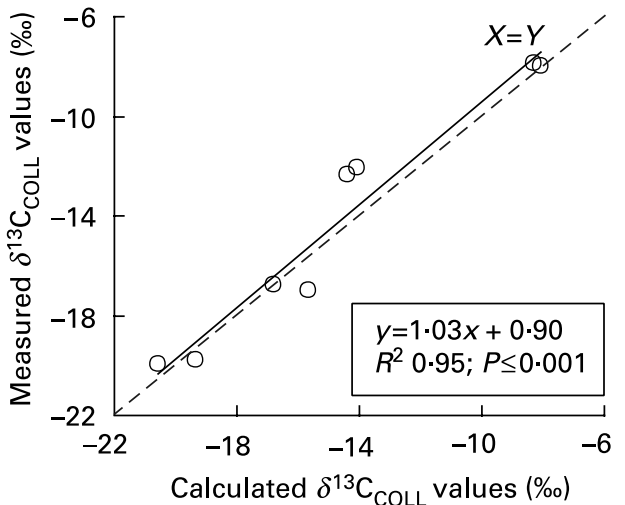

Fig. 1. Linear correlations between calculated and measured bulk collagen $\delta^{13} \mathrm{C}\left(\delta^{13} \mathrm{C}_{\mathrm{COLL}}\right)$ values (dotted line represents where $\left.x=y\right)$. Values were calculated using constituent amino acid $\delta^{13} \mathrm{C}$ values via mass balance equations. For details of procedures, see Materials and methods. Measured amino acids constituted approximately $84 \%$ of the carbon in bone collagen.

$(< \pm 2 \%$ ) , thereby validating the measured individual AA $\delta^{13} \mathrm{C}$ values.

\section{Compound-specific diet and bone collagen amino acid $\delta^{13} \mathrm{C}$ values}

Table 3 and Fig. 2 present rat diet and corresponding bone collagen AA $\delta^{13} \mathrm{C}$ values for the four diets studied. The $\delta{ }^{13} \mathrm{C}$ values of nine of the most abundant AA from the pure $\mathrm{C}_{3}(\mathrm{C} 3)$ diet and pure $\mathrm{C}_{4}(\mathrm{C} 4)$ diet, and the average collagen $\mathrm{AA} \delta{ }^{13} \mathrm{C}$ values of the two animals raised on these diets are presented in Fig. 2(a). Ranges of approximately 18 and $21 \%$ are observed in the $\delta^{13} \mathrm{C}$ values of diet and collagen AA, respectively, which are comparable to those reported previously (Tuross et al. 1988; van Klinken, 1989; Hare et al. 1991). Incorporation of the isotopic signal from dietary AA to bone AA can be clearly seen resulting in small and largely insignificant isotopic differences $\left(\Delta^{13} \mathrm{C}_{b \mathrm{AA}-d \mathrm{AA}}=\delta^{13} \mathrm{C}_{b \mathrm{AA}}-\delta^{13} \mathrm{C}_{d \mathrm{AA}}\right)$ between bone collagen $\left(\delta^{13} \mathrm{C}_{b \mathrm{AA}}\right)$ and diet $\left(\delta^{13} \mathrm{C}_{d \mathrm{AA}}\right) \mathrm{AA} \delta^{13} \mathrm{C}$ values for both essential and non-essential AA (Table 3). Non-essential AA can be biosynthesised by the body from a variety of different carbon sources, as well as being incorporated directly from the diet. However, as these diets have similar protein and energy macronutrient $\delta^{13} \mathrm{C}$ values, similar $\Delta^{13} \mathrm{C}_{b \mathrm{AA}-d \mathrm{AA}}$ values are expected to be observed for all bone AA. A true assessment of the balance between AA absorption and de novo synthesis can only be gleaned when animals are raised on diets where the different macronutrients have different $\delta^{13} \mathrm{C}$ values, i.e. from the mixed $\mathrm{C}_{3} / \mathrm{C}_{4}$ diets.

Figure 2(b, c) compares the $\delta^{13} \mathrm{C}$ values of diet and bone AA for the four rats raised on diets where the macronutrients have different $\delta^{13} \mathrm{C}$ values. For the $\mathrm{C}_{3}$ protein and $\mathrm{C}_{4}$ energy (C3P/C4E) diet (Fig. 2(b)), enriched $\delta{ }^{13} \mathrm{C}$ values are shown for alanine, glycine, proline, aspartate and glutamine reflecting the contribution of dietary $\mathrm{C}_{4}$ carbon from the non-protein or energy macronutrients to the biosynthesis of these AA in collagen. The same energy macronutrient carbon contribution is also reflected in the collagen AA of animals raised on the $\mathrm{C}_{4}$ protein and $\mathrm{C}_{3}$ energy (C4P/C3E) diet (Fig. 2(c)), resulting in more depleted $\delta^{13} \mathrm{C}$ values for all of the same AA mentioned earlier, except for proline. As expected for both of these diets, the $\delta^{13} \mathrm{C}$ values of essential AA in collagen, isoleucine, leucine and phenylalanine were shown to reflect those in the diet with only one exception, where $\Delta^{13} \mathrm{C}_{b \mathrm{AA}-d \mathrm{AA}}=-4.9 \quad( \pm 1.7) \%$ for leucine from the C4P/C3E diet. Essential AA comprise $21.7 \%$ of the carbon in collagen (collagen AA composition from Francois \& Glimcher, 1967) and cannot incorporate any of the dietary energy macronutrient carbon isotope signal. With the exception of leucine, statistically identical $\delta^{13} \mathrm{C}$ values were observed for diet and bone collagen essential AA, indicating that no detectable fractionations occurred as a result of transport and/or assimilation (Table 4). In contrast to the pure $\mathrm{C}_{3}$ and pure $\mathrm{C}_{4}$ diets, much larger $\Delta^{13} \mathrm{C}_{b \mathrm{AA}-d \mathrm{AA}}$ values are demonstrated for the non-essential $\mathrm{AA}$ for the animals raised on these mixed $\mathrm{C}_{3} / \mathrm{C}_{4}$ diets. The largest $\Delta^{13} \mathrm{C}_{b \mathrm{AA}-d \mathrm{AA}}$ values were observed for alanine where $\Delta^{13} \mathrm{C}_{b \mathrm{AA}-d \mathrm{AA}}$ was equal to $17.0( \pm 2.5) \%$ and $-19.7( \pm 2.2) \%$ o for the C3P/C4E and C4P/C3E diets, respectively.

\section{Relationship between bulk whole diet and bone collagen $\delta^{13} \mathrm{C}$ values}

The compound specific $\delta^{13} \mathrm{C}$ values of individual bone AA were measured to deconvolute bulk collagen $\delta^{13} \mathrm{C}$ values and help define its relationship to whole diet, i.e. $\Delta^{13} \mathrm{C}_{\mathrm{COLL}}$ wDIET. A range of $\Delta^{13} \mathrm{C}_{\text {COLL-WDIET values are observed for }}$ these diets (Table 2); relatively consistent mean values of 5.2 and $4.4 \%$ are shown for the $\mathrm{C} 3$ and $\mathrm{C} 4$ diets, respectively, but the $\mathrm{C} 3 \mathrm{P} / \mathrm{C} 4 \mathrm{E}$ and $\mathrm{C} 4 \mathrm{P} / \mathrm{C} 3 \mathrm{E}$ diets displayed values of $-2 \cdot 2$ and $10 \%$, respectively. Therefore, the $\Delta^{13} \mathrm{C}_{\mathrm{COLL}}$-WDIET values for the mixed $\mathrm{C}_{3} / \mathrm{C}_{4}$ diets represented a departure of approximately $6.0 \%$ from pure $C_{3}$ and pure $C_{4}$ values. This reflects the contribution of dietary energy macronutrient carbon to the biosynthesis of bone collagen. The relative enrichments or depletions in ${ }^{13} \mathrm{C}$ in the non-essential AA of these animals, which constitute approximately $80 \%$ of the carbon in bone collagen, can result in such disparate $\Delta^{13} \mathrm{C}_{\mathrm{COLL}}$-WDIET values. Such variations in ${ }^{13} \mathrm{C}$ in the non-essential AA of these animals provide a basis for obtaining new insights into the extent to which dietary AA contribute to protein biosynthesis.

We postulate that there exists a threshold percentage of protein $\left(\%\right.$ prot $\left._{\text {threshold }}\right)$ in the diet where collagen $\delta^{13} \mathrm{C}$ values would represent those contributed by dietary protein. Models of the relationship between the $\delta^{13} \mathrm{C}$ values of diet (whole diet, protein and energy) and bone (cholesterol, collagen and apatite) constructed from this feeding experiment suggest that $5 \%<\%$ prot $_{\text {threshold }}<12 \%$ (Jim, 2000). Since these diets comprise $20 \%$ protein, there would have been an excess of the amount required for net growth and tissue turnover. Therefore, routing of non-essential AA directly from the diet is likely to occur because in terms of the conservation of energy, this is more efficient than de novo synthesis. In fact, an estimate of the amount of routing of dietary to bone collagen AA that can be expected when the diet supplies an excess of each AA is approximately $65 \%$ (Ambrose et al. 1997). The amount of routing in the controlled diet experiments reported by Ambrose and Norr (1993, figure 5) is $52.3 \%$. 
Table 3. Diet and bone amino acid $\delta^{13} \mathrm{C}$ values, and $\Delta^{13} \mathrm{C}_{b \mathrm{AA}-d \mathrm{AA}}$ spacings* with their errors

\begin{tabular}{|c|c|c|c|c|c|c|c|}
\hline \multirow[b]{3}{*}{ Diet codes† } & \multirow[b]{3}{*}{ Amino acid } & \multicolumn{4}{|c|}{ Amino acid $\delta^{13} \mathrm{C}(\% \circ)$} & & \\
\hline & & \multicolumn{2}{|c|}{ Diet } & \multicolumn{2}{|c|}{ Bone } & \multicolumn{2}{|c|}{$\Delta^{13} \mathrm{C}_{b \mathrm{AA}-d \mathrm{AA}}(\% \circ) \ddagger$} \\
\hline & & Mean & \pm & Mean & \pm & Mean & \pm \\
\hline \multirow[t]{8}{*}{$\mathrm{D} 2 \mathrm{~A}-\mathrm{C} 3$} & Ala & -22.9 & $1 \cdot 1$ & -24.4 & $1 \cdot 6$ & -1.5 & 1.9 \\
\hline & Gly & $-16 \cdot 4$ & $1 \cdot 3$ & $-15 \cdot 1$ & $2 \cdot 0$ & $1 \cdot 3$ & $2 \cdot 4$ \\
\hline & Pro§ & $-18 \cdot 4$ & 0.7 & -15.5 & $1 \cdot 1$ & 2.9 & $1 \cdot 3$ \\
\hline & Asp & $-21 \cdot 7$ & $1 \cdot 1$ & $-21 \cdot 3$ & 1.4 & 0.4 & $1 \cdot 8$ \\
\hline & Glu & $-16 \cdot 8$ & 0.8 & -15.0 & $1 \cdot 2$ & $1 \cdot 8$ & 1.4 \\
\hline & Ile\| & $-28 \cdot 8$ & $2 \cdot 8$ & $-26 \cdot 1$ & $2 \cdot 2$ & $2 \cdot 7$ & $3 \cdot 6$ \\
\hline & Leu\| & -32.9 & 0.8 & $-34 \cdot 3$ & 1.0 & -1.4 & $1 \cdot 3$ \\
\hline & Phe\|l & $-29 \cdot 1$ & $1 \cdot 2$ & -28.0 & $1 \cdot 2$ & $1 \cdot 2$ & $2 \cdot 0$ \\
\hline \multirow[t]{8}{*}{ D3G - C3P/C4E } & Ala & -30.5 & $1 \cdot 1$ & -13.5 & $2 \cdot 3$ & $17 \cdot 0$ & 2.5 \\
\hline & Gly & $-26 \cdot 4$ & 1.5 & -15.9 & $1 \cdot 8$ & $10 \cdot 5$ & $2 \cdot 3$ \\
\hline & Pro§ & -19.7 & 0.9 & -14.9 & 1.9 & $4 \cdot 8$ & $2 \cdot 1$ \\
\hline & Asp & -23.9 & $1 \cdot 3$ & $-12 \cdot 6$ & 1.5 & $11 \cdot 3$ & $2 \cdot 0$ \\
\hline & Glu & $-18 \cdot 5$ & $1 \cdot 1$ & -6.0 & 1.9 & $12 \cdot 5$ & $2 \cdot 2$ \\
\hline & $\|e\|$ & $-29 \cdot 7$ & 0.9 & $-29 \cdot 0$ & $1 \cdot 2$ & 0.7 & 1.5 \\
\hline & Leu\| & $-33 \cdot 3$ & 0.8 & $-33 \cdot 4$ & $1 \cdot 2$ & -0.1 & 1.4 \\
\hline & Phe\|l & $-27 \cdot 4$ & 0.5 & $-27 \cdot 6$ & 0.8 & -0.1 & 0.9 \\
\hline \multirow[t]{8}{*}{$\mathrm{D} 4 \mathrm{H}-\mathrm{C} 4$} & Ala & $-16 \cdot 3$ & 0.8 & $-10 \cdot 8$ & $1 \cdot 1$ & 5.5 & 1.4 \\
\hline & Gly & -4.7 & 1.5 & $-6 \cdot 6$ & $2 \cdot 2$ & -1.9 & $2 \cdot 7$ \\
\hline & Pro§ & $-7 \cdot 6$ & 0.6 & $-4 \cdot 2$ & $1 \cdot 7$ & 3.4 & $1 \cdot 8$ \\
\hline & Asp & $-11 \cdot 0$ & 0.9 & $-9 \cdot 3$ & $2 \cdot 3$ & $1 \cdot 7$ & $2 \cdot 5$ \\
\hline & Glu & $-2 \cdot 1$ & 0.9 & $-1 \cdot 2$ & $1 \cdot 2$ & 0.9 & 1.5 \\
\hline & \|le\| & $-17 \cdot 8$ & 1.9 & $-16 \cdot 9$ & $3 \cdot 1$ & 0.9 & $3 \cdot 7$ \\
\hline & Leull & $-21 \cdot 7$ & 0.8 & $-23 \cdot 8$ & 0.9 & $-2 \cdot 1$ & $1 \cdot 2$ \\
\hline & Phe\|l & $-17 \cdot 0$ & 0.7 & $-17 \cdot 7$ & $1 \cdot 3$ & -0.6 & 1.5 \\
\hline \multirow[t]{8}{*}{ D5I - C4P/C3E } & Ala & -9.8 & $1 \cdot 8$ & -29.5 & $1 \cdot 3$ & -19.7 & $2 \cdot 2$ \\
\hline & Gly & $-7 \cdot 0$ & 1.5 & $-12 \cdot 5$ & $1 \cdot 7$ & -5.5 & $2 \cdot 3$ \\
\hline & Pro§ & -9.8 & 1.0 & -5.2 & $1 \cdot 2$ & 4.6 & 1.5 \\
\hline & Asp & -12.9 & 1.5 & $-15 \cdot 3$ & 1.6 & -2.4 & $2 \cdot 2$ \\
\hline & Glu & $-5 \cdot 2$ & 0.9 & $-12 \cdot 0$ & 1.4 & -6.8 & 1.6 \\
\hline & Ile\| & -16.5 & $1 \cdot 2$ & $-16 \cdot 0$ & $2 \cdot 3$ & 0.5 & 2.6 \\
\hline & Leu\| & $-21 \cdot 3$ & 0.8 & $-26 \cdot 2$ & 1.5 & -4.9 & 1.7 \\
\hline & Phe\|l & $-18 \cdot 4$ & 0.5 & -15.9 & $1 \cdot 1$ & 2.6 & 1.6 \\
\hline
\end{tabular}

${ }^{*}$ For procedures and diet composition, see Materials and methods and Table 1.

$+\mathrm{C} 3$, pure $\mathrm{C}_{3}$ diet; C3P/C4E, $\mathrm{C}_{3}$ protein/ $\mathrm{C}_{4}$ energy diet; $\mathrm{C} 4$, pure $\mathrm{C}_{4}$ diet; $\mathrm{C} 4 \mathrm{P} / \mathrm{C} 3 \mathrm{E}, \mathrm{C}_{4}$ protein $/ \mathrm{C}_{3}$ energy diet.

‡Differences between bone collagen $\left(\delta^{13} \mathrm{C}_{b A A}\right)$ and diet $\left(\delta^{13} \mathrm{C}_{d A A}\right)$ amino acid $\delta^{13} \mathrm{C}$ values $\left(\Delta^{13} \mathrm{C}_{b A A-d A A}=\delta^{13} \mathrm{C}_{b A A}-\delta^{13} \mathrm{C}_{d A A}\right)$.

$\S$ Conditionally indispensable amino acid.

\| Essential amino acid.

Qualitative estimation of dietary carbon to bone collagen biosynthesis

The relationship between diet and bone AA $\delta^{13} \mathrm{C}$ values was investigated further using linear regression. Table 4 summarises the $R^{2}$ and $P$ values observed between each diet and bone $\mathrm{AA}$, and significant correlations where $P<0.05$ are underlined. Not surprisingly, all the essential dietary AA $\delta^{13} \mathrm{C}$ values correlate well with those in bone collagen $\left(0.69<R^{2}<0.96\right.$ and $\left.0.0106<P<0.00002\right)$. This was also shown to be true for proline $\left(R^{2} 0.99, P<0.001\right)$ and a significant although somewhat poorer correlation was demonstrated for glycine $\left(R^{2} 0 \cdot 58, P<0.05\right)$. The present findings provide direct evidence for the routing of the essential AA from the diet to bone collagen. Although proline is traditionally categorised as a non-essential AA, it has been shown to be essential in growing mammals ("conditionally essential'; Ball et al. 1986; Chung \& Baker, 1993) and the data presented herein represents the first natural abundance stable isotopic evidence for the direct incorporation of proline from the diet into bone collagen. The present findings also show that bone collagen glycine $\delta^{13} \mathrm{C}$ values are significantly affected by dietary values, again providing evidence of direct routing from the diet. In contrast, the low $R^{2}(<0.41)$ and high $P$ values $(>0.05)$ demonstrated for the remaining nonessential AA, alanine, aspartate and glutamine, indicate that de novo synthesis dominates over the direct incorporation of these AA from the diet to collagen.

\section{Quantitative estimation of dietary carbon to bone collagen biosynthesis}

Greater insight into the extent of routing of dietary AA into bone AA can be gleaned from plotting $\Delta^{13} \mathrm{C}_{b \mathrm{AA} \text {-WDIET fractio- }}$ nations against their corresponding $\Delta^{13} \mathrm{C}_{d \mathrm{AA} \text {-WDIET spacings }}$ ( $=\delta{ }^{13} \mathrm{C}_{\text {dietAA }}-\delta{ }^{13} \mathrm{C}_{\text {whole diet }}$ ). We focus here on the $R^{2}$ values and slopes of the 'double delta' regression equations in Fig. 3 to interpret diet-to-bone collagen AA relationships. $R^{2}$ values ranged from 0.76 to $0.98(P<0.05)$, showing that these relationships correlated well to very well with each other. We interpret the slopes observed for each AA as roughly equivalent to the proportion of carbon routed from dietary protein to that AA. With lower $R^{2}$ values, the accuracy of estimation of routing using the slopes of these regressions 

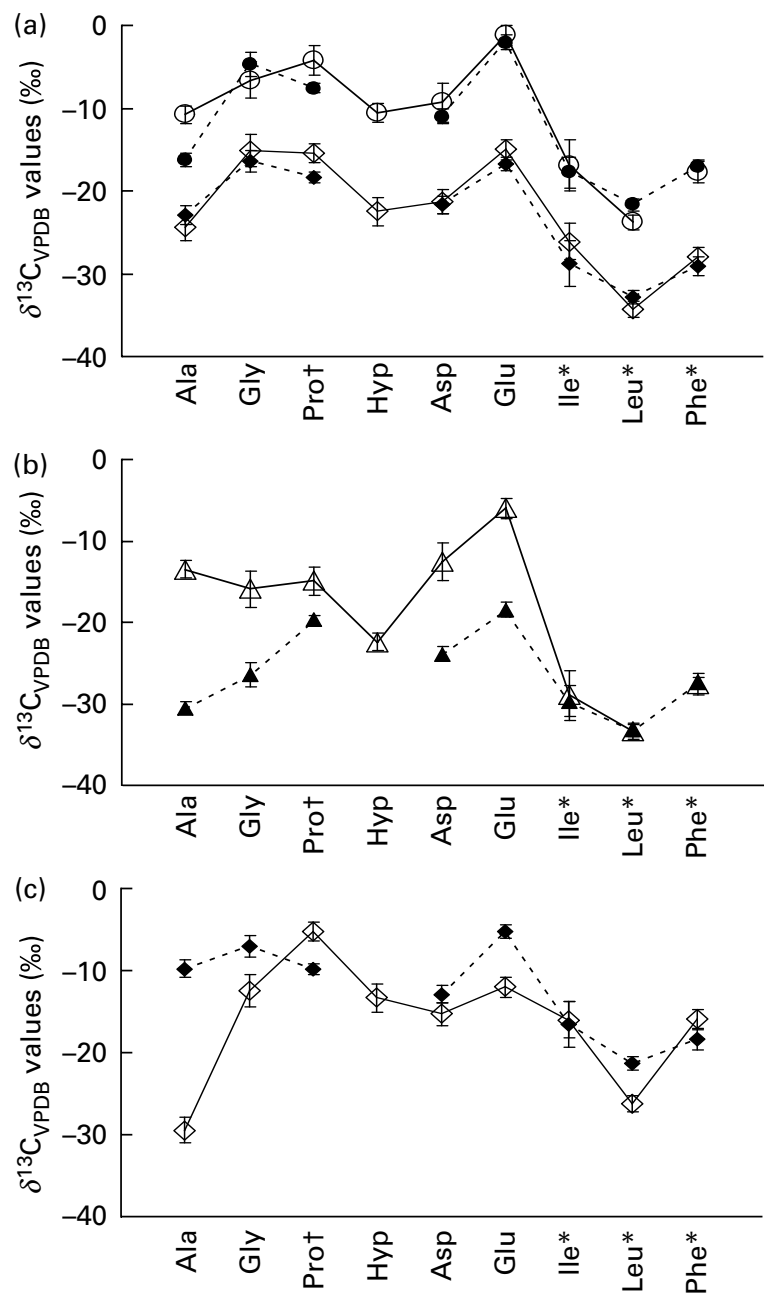

Fig. 2. Graph showing dietary and collagen amino acid $(A A) \delta^{13} \mathrm{C}$ values for rats raised on the pure $C_{3}$ diet $(\diamond$, dietary $A A ; \diamond$, collagen $A A)$ and pure $C_{4}$ ( $\bullet$, dietary $A A ; O$, collagen $A A)$ diet (a); $C_{3}$ protein $/ C_{4}$ energy ( $\Delta$, dietary $A A$; $\triangle$, collagen $A A$ ) diet $(b) ; C_{4}$ protein $/ C_{3}$ energy ( $\bullet$, dietary $A A ; \diamond$, collagen $\left.A A\right)$ diet (c). For details of procedures, see Materials and methods. Values are means with their errors depicted by vertical bars (collagen $A A \delta^{13} \mathrm{C}$ values are means of two animals). ${ }^{\star}$ Essential AA; †conditionally indispensable AA.

declines. Significant differences in the slopes of these regression lines are observed, demonstrating the varying degrees to which $\Delta^{13} \mathrm{C}_{b \mathrm{AA}-W D I E T}$ fractionations depend on the difference between dietary $\mathrm{AA}$ and whole diet $\delta^{13} \mathrm{C}$

Table 4. $R^{2}$ and $P$ values from linear correlations of diet versus bone amino acid $\delta^{13} \mathrm{C}$ values*

\begin{tabular}{|c|c|c|}
\hline Amino acid & $R^{2}$ & $P$ \\
\hline Ala & 0.41 & 0.1231 \\
\hline Gly & 0.58 & 0.0452 \\
\hline Prot & 0.97 & 0.0000 \\
\hline Asp & 0.40 & 0.1273 \\
\hline Glu & 0.17 & 0.3042 \\
\hline lleł & 0.97 & 0.0000 \\
\hline Leuł & 0.93 & 0.0001 \\
\hline Pheł & 0.93 & 0.0001 \\
\hline
\end{tabular}

* Significant correlations $(P<0.05)$ are in bold.

† Conditionally indispensable amino acid.

‡Essential amino acid values. Slopes close to unity are observed for the essential AA (isoleucine, leucine and phenylalanine) and for conditionally indispensable proline, and this can be interpreted as indicating that almost all of the carbon atoms in these bone collagen AA are derived from the corresponding dietary AA, reflecting their direct incorporation. The deviation from unity in slopes for isoleucine and proline appear to be due to single outliers. Lower slopes and $R^{2}$ values are shown for glycine and aspartate corresponding to routing estimates of 42 and $28 \%$, respectively. In total, an estimate of the routing of non-essential AA is equal to $29.6 \%$ of the carbon in collagen. However, given the low $R^{2}$ for these regressions, accurate estimation of routing of non-essential AA will require the analysis of larger numbers of individuals on different diets. When the contribution of carbon from the essential AA is also considered, we arrive at an overall minimum estimate of $51.3 \%$ routing of dietary AA carbon into bone collagen. This value compares well to $65 \%$, which was postulated for animals raised on diets with greater than $12 \%$ protein (Ambrose et al. 1997). It also compares well with the estimate of $52.3 \%$, derived from the slope of the regression of $\Delta^{13} \mathrm{C}_{\text {COLlagen-wdiet }}$ against $\Delta^{13} \mathrm{C}_{\text {PROTEIN-wdiet }}$ for seven litters of rats in a larger study (Ambrose \& Norr, 1993, Fig. 5) from which our samples for isotopic analysis of AA were drawn.

\section{Summary}

Stable carbon isotope analysis of tissue biochemical fractions at the molecular level reveals information that is hidden within bulk isotope values and thus allows the study of the finer details of metabolic pathways and biochemical processes that underpin tissue formation. The use of naturally labelled rather than enriched stable isotope- or radioisotope-labelled nutrients significantly reduces costs and risks of contamination, and simplifies the design of controlled diet experiments. Isotopic analysis of the individual AA of diets and consumer tissue proteins permits us to identify the AA in which routing is concentrated, and thus to determine the degree to which non-essential AA behave like essential AA. This may provide a useful tool for investigating changes in AA metabolism during growth, nutritional stress and other metabolic stresses.

The present investigation has shown for the first time using a natural abundance stable isotope approach that it is possible to estimate qualitatively and quantitatively the routing and neosynthesis of individual AA from different dietary macronutrients into bone collagen. Our results support the new tripartite division of AA into indispensable (essential), conditionally indispensable (conditionally essential) and dispensable (nonessential) AA (Young \& El-Khoury, 1995; Reeds, 2000) and show that the routing of carbon from dietary protein to bone collagen is higher in AA that are now classified as conditionally indispensable or conditionally essential. Conditionally indispensable AA are those whose endogenous neosynthesis is inadequate to sustain normal growth rates or recovery from illness or injury when they are absent from the diet (Young \& El-Khoury, 1995; Reeds, 2000). Such AA require a greater number of energetically expensive steps for their synthesis de novo (Voet \& Voet, 1995). 

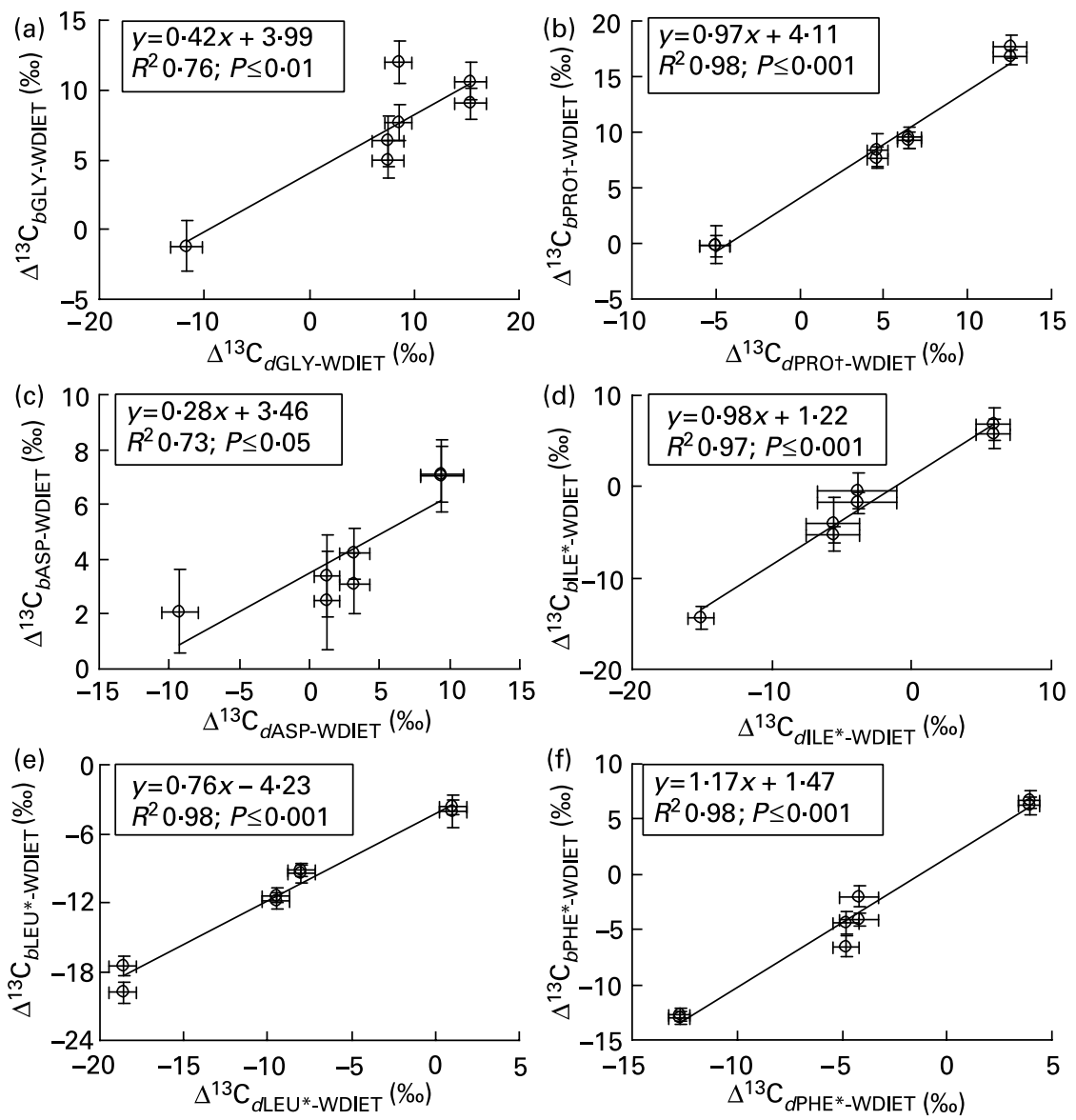

Fig. 3. 'Double delta' correlations of $\Delta^{13} \mathrm{C}_{d A A-W D I E T}$ spacings $\left(=\delta^{13} \mathrm{C}_{\text {diet amino acid }}-\delta^{13} \mathrm{C}_{\text {whole diet }}\right)$ versus corresponding $\Delta^{13} \mathrm{C}_{b A A-W D I E T}$ fractionations $\left(=\delta^{13} \mathrm{C}_{\text {bone }}\right.$ amino acid $-\delta^{13} C_{\text {whole diet }}$ ) for: glycine (a); proline (b); aspartate (c); isoleucine (d); leucine (e); phenylalanine (f). We interpret the slope of each graph as equivalent to the proportion of carbon routed from dietary protein to that $A A$. *Essential AA, tconditionally indispensable AA.

We postulate that on low-protein diets, where protein and non-protein $\delta{ }^{13} \mathrm{C}$ values differ and the amount of protein is below the threshold of the minimum AA requirements, that non-essential collagen $\mathrm{AA} \delta{ }^{13} \mathrm{C}$ values will become increasingly dissimilar to essential AA values as more non-protein carbon is required for their synthesis de novo. In other words, we expect more neosynthesis of the conditionally indispensable AA when the dietary protein source is insufficient. Conversely, on high-protein diets, we can expect that non-essential collagen AA $\delta{ }^{13} \mathrm{C}$ values will become increasingly 'similar' to essential AA values as more non-essential AA are routed directly from the diet. However, these variations in the isotopic relationship between non-essential and essential AA must be distinguishable from their natural isotopic relationships which are due to differences in their biochemical pathways. These hypotheses will be the subject of future studies of animals raised on low- and high-protein diets. If their potential is realised, we may be able to gain qualitative and quantitative insights into the type of protein present in the diet of modern and fossil animals.

\section{Acknowledgements}

This work was completed while the authors were in receipt of the following grants: a Bioarchaeology Fellowship (057166/Z/ 99/Z) from The Wellcome Trust to S. J. and an EPSRC studentship to V. J. NERC is thanked for financial support for MS facilities (GR3/2951, GR3/3758 and FG6/36/01). We also thank Dr Jim Carter and Mr Andrew Gledhill for technical assistance with GC/MS and GC/C/IRMS. Rat feeding experiments were supported by the National Science Foundation, USA (BNS 9010937 and SBR 9212466) and the University of Illinois Research Board.

\section{References}

Ambrose SH (1993) Isotopic analysis of paleodiets: methodological and interpretive considerations. In Investigation of Ancient Human Tissue, Chemical Analyses in Anthropology, pp. 59-130 [MK Sandford, editor]. Langhorne, PA: Gordon and Breach Scientific.

Ambrose SH, Butler BM, Hanson DB, Hunter-Anderson RL \& Krueger HW (1997) Stable isotopic analysis of human diet in the Marianas Archipelago, Western Pacific. Am J Phys Anthropol 104, 343-361.

Ambrose SH \& Norr L (1993) Experimental evidence for the relationship of the carbon isotope ratios of whole diet and dietary protein to those of bone collagen and carbonate. In Prehistoric Human Bone - Archaeology at the Molecular Level, pp. 1-37 [JB Lambert and G Grupe, editors]. Berlin: Springer-Verlag.

Atasoglu C, Guliye AY \& Wallace RJ (2004) Use of stable isotopes to measure de novo synthesis and turnover of amino acid-C and $-\mathrm{N}$ in mixed micro-organisms from the sheep rumen in vitro. $\mathrm{Br} \mathrm{J} \mathrm{Nutr}$ 91, 253-261. 
Ayliffe LK, Cerling TE, Robinson T, West AG, Sponheimer M, Passey BH, Hammer J, Roeder B, Dearing MD \& Ehleringer JR (2004) Turnover of carbon isotopes in tail hair and breath $\mathrm{CO}_{2}$ of horses fed an isotopically varied diet. Oecologia 139, $11-22$.

Ball RO, Atkinson JL \& Bayley HS (1986) Proline as an essential amino acid for the young pig. Br J Nutr 55, 659-668.

Bocherens H \& Drucker D (2003) Trophic level isotopic enrichment of carbon and nitrogen in bone collagen: case studies from recent and ancient terrestrial ecosystems. Int J Osteoarchaeol 13, 46-53.

Brenna JT (2001) Natural intramolecular isotope measurements in physiology: elements of the case for an effort toward high-precision position-specific isotope analysis. Rapid Commun Mass Spectrom 15, 1252-1262.

Chisholm BS (1986) Reconstruction of prehistoric diet in British Columbia using stable carbon isotopic analysis. PhD Thesis, Simon Fraser University.

Chung TK \& Baker DH (1993) A note on the dispensability of proline for weanling pigs. Anim Prod 56, 407-408.

Craig H (1957) Isotopic standards for carbon and oxygen and correction factors for mass-spectrometric analysis of carbondioxide. Geochim Cosmochim Acta 12, 133-149.

DeNiro MJ \& Epstein S (1978) Influence of diet on the distribution of carbon isotopes in animals. Geochim Cosmochim Acta 42, 495-506.

Docherty G, Jones V \& Evershed RP (2001) Practical and theoretical considerations in the gas chromatography/combustion/isotope ratio mass spectrometry $\delta^{13} \mathrm{C}$ analysis of small polyfunctional compounds. Rapid Commun Mass Spectrom 15, 730-738.

Francois CJ \& Glimcher MJ (1967) Isolation and amino acid composition of alpha chains of chicken bone collagen. Biochim Biophys Acta 133, 91.

Fuller MF \& Garlick PJ (1994) Human amino acid requirements: can the controversy be resolved? Annu Rev Nutr 14, 217-241.

Gannes LZ, Martìnez de Rio C \& Koch P (1998) Natural abundance variations in stable isotopes and their potential uses in animal physiological ecology. Comp Biochem Physiol 119A, 725-737.

Guillet C, Boirie Y \& Walrand S (2004) An integrative approach to in-vivo protein synthesis measurements: from whole tissues to specific proteins. Curr Opin Clin Nutr Metab Care 7, 531-538.

Hare PE, Fogel ML, Stafford TW Jr, Mitchell AD \& Hoering TC (1991) The isotopic composition of carbon and nitrogen in individual amino acids isolated from modern and fossil proteins. J Archaeol Sci 18, 277-292.

Howland MR, Corr LT, Young SMM, Jones V, Jim S, van der Merwe NJ, Mitchell AD \& Evershed RP (2003) Expression of the dietary isotope signal in the compound-specific $\delta^{13} \mathrm{C}$ values of pig bone lipids and amino acids. Int J Osteoarchaeol 13, 54-65.

Jim S (2000) The development of bone cholesterol $\delta^{13} \mathrm{C}$ values as a new source of palaeodietary information: models of its use in conjunction with bone collagen and apatite $\delta^{13} \mathrm{C}$ values. $\mathrm{PhD}$ Thesis, University of Bristol.

Jim S, Ambrose SH \& Evershed RP (2003) Stable carbon isotopic evidence for the routing and de novo synthesis of bone fatty acids and cholesterol. Lipids 38, 179-186.

Jim S, Ambrose SH \& Evershed RP (2004) Stable carbon isotopic evidence for differences in the biosynthetic origin of bone cholesterol, collagen and apatite: implications for their use in palaeodietary reconstruction. Geochim Cosmochim Acta 68, $61-72$.
Jim S, Jones V, Copley MS, Ambrose SH \& Evershed RP (2003) Effect of hydrolysis on the $\delta^{13} \mathrm{C}$ values of amino acids derived from polypeptides and proteins. Rapid Commun Mass Spectrom 17, 2283-2289.

Krueger HW \& Sullivan CH (1984) Models for carbon isotope fractionation between diet and bone. In Stable Isotopes in Human Nutrition, pp. 205-220 [JS Turnlund and PE Johnson, editors]. Washington, DC: American Chemical Society.

Lee-Thorp JA, Sealy JC \& van der Merwe NJ (1989) Stable carbon isotope ratio differences between bone collagen and bone apatite, and their relationship to diet. J Archaeol Sci 16, 585-599.

Lee-Thorp JA, Sponheimer M \& van der Merwe NJ (2003) What do stable isotopes tell us about hominid dietary and ecological niches in the Pliocene? Int J Osteoarchaeol 13, 104-113.

Macko SA, Uhle ME, Engel MH \& Andrusevich V (1997) Stable nitrogen isotope analysis of amino acid enantiomers by gas chromatography/combustion/isotope ratio mass spectrometry. Anal Chem 69, 926-929.

Morrison DJ, Dodson B, Slater C \& Preston T $(2000){ }^{13} \mathrm{C}$ natural abundance in the British diet: implications for ${ }^{13} \mathrm{C}$ breath tests. Rapid Commun Mass Spectrom 14, 1321-1324.

O'Brien DM, Fogel ML \& Boggs CL (2002) Renewable and nonrenewable resources: amino acid turnover and allocation to reproduction in lepidoptera. Proc Natl Acad Sci USA 99, 4413-4418.

Reeds P (2000) Dispensable and indispensable amino acids for humans. J Nutr 130, S1835-S1840.

Savidge WB \& Blair NE (2004) Seasonal and within-plant gradients in the intramolecular carbon isotopic composition of amino acids of Spartina alterniflora. J Exp Mar Biol Ecol 308, $151-167$.

Schwarcz HP (2000) Some biochemical aspects of carbon isotopic paleodiet studies. In Biogeochemical Approaches to Paleodietary Analysis, pp. 189-209 [SH Ambrose and MA Katzenberg, editors]. New York: Kluwer/Plenum.

Tieszen LL \& Boutton TW (1988) Stable carbon isotopes in terrestrial ecosystem research. In Stable Isotopes in Ecological Research, pp. 167-195 [PW Rundel, JR Ehleringer and KA Nagy, editors]. London: Springer.

Tieszen LL \& Fagre T (1993) Effect of diet quality and composition on the isotopic composition of respiratory $\mathrm{CO}_{2}$, bone collagen, bioapatite, and soft tissues. In Prehistoric Human Bone - Archaeology at the Molecular Level, pp. 121-155 [JB Lambert and G Grupe, editors]. Berlin: Springer-Verlag.

Tuross N, Fogel ML \& Hare PE (1988) Variability in the preservation of the isotopic composition of collagen from fossil bone. Geochim Cosmochim Acta 52, 929-935.

van Klinken GJ (1989) Note on the isolation of single amino acids from fossil bone. Appl Geochem 4, 271.

Voet D \& Voet JG (1995) Amino acid biosynthesis. In Biochemistry, pp. 764-776. New York: John Wiley and Sons.

Wu CC, MacCoss MJ, Howell KE, Matthews DE \& Yates JR III (2004) Metabolic labelling of mammalian organisms with stable isotopes for quantitative proteomic analysis. Anal Chem 76, 4951-4959.

Young VR \& El-Khoury AE (1995) The notion of the nutritional essentiality of amino acids, revisited, with a note on the indispensable amino acid requirements in adults. In Amino Acid Metabolism and Therapy in Health and Nutritional Disease, pp. 191-232 [LA Cynober, editor]. Boca Raton, FL: CRC Press. 